\title{
Snail grazing facilitates growth of a bloom-forming alga
}

\author{
Michele Guidone $^{1, *}$, Carol S. Thornber ${ }^{1}$, Emily Field ${ }^{1,2}$ \\ ${ }^{1}$ Department of Biological Sciences, University of Rhode Island, Kingston, Rhode Island 02881, USA \\ ${ }^{2}$ Department of Biological Science, Florida State University, Tallahassee, Florida 32306, USA
}

\begin{abstract}
Herbivory often has a negative effect on plants. However, there is a growing number of examples, primarily in terrestrial ecosystems, where herbivory causes an increase in plant size, growth rate, and/or reproductive output. In marine ecosystems, the positive effects of herbivores on macroalgae are not as well studied, although limited evidence exists for herbivore-induced increases in macroalgal growth rates via 2 mechanisms: nutrient addition via grazer defecation, and epiphyte removal. In this study, we examined the effects of grazing by the mud snail Ilyanassa obsoleta on Ulva lactuca, the dominant bloom-forming macroalga in many New England estuaries. We found that the presence of $I$. obsoleta had a significant positive, rather than negative, effect on U. lactuca. Through caging experiments, we established that this positive effect was not due to fecal nutrient inputs from the snail. Similarly, snail contact in the absence of grazing did not affect $U$. lactuca growth rates. In contrast, grazing by I. obsoleta significantly reduced the microalgal cover on heavily fouled U. lactuca blades, indicating that snail herbivory of microalgal films likely facilitates U. lactuca growth. Our study demonstrates the surprising, positive effect that an abundant herbivore can have on the growth of a macroalgal bloom species.
\end{abstract}

KEY WORDS: Facilitation · Compensation · Herbivory · Algal bloom · Ulva lactuca $\cdot$ Ilyanassa obsoleta

\section{INTRODUCTION}

The negative effects of herbivores on primary producers are well known. However, research in terrestrial, aquatic, and marine systems is increasingly revealing instances where herbivory can positively influence plants and algae via a variety of mechanisms. Overcompensation, a phenomenon where plants experiencing light to moderate herbivory have a higher growth rate and/or reproductive output than related, undamaged plants (Agrawal 2000), has been observed in a wide range of plant-herbivore interactions, including multiple species of grasses and ungulates (McNaughton 1979, Lennartsson et al. 1997), scarlet gilia and ungulates (Gronemeyer et al. 1997, Paige 1999), pondweed and swans (Nolet 2004), and turtlegrass and sea urchins (Valentine et al. 1997). Herbivory can also positively impact plants through indirect pathways, such as fertilization via herbivore nitrogenous wastes (McNaughton 1983, 1997, Bazely \& Jefferies 1985) or the preferential grazing of neighboring or epiphytic competitors (Dudley 1992, Littler et al. 1995, Stachowicz \& Hay 1996, Jernakoff \& Nielson 1997, Kamermans et al. 2002, Hughes et al. 2004).

One trophic relationship that has recently attracted attention is the effect of herbivores on bloom-forming macroalgae in coastal ecosystems throughout the world. Macroalgal blooms result from a variety of environmental cues, including anthropogenic nitrogen inputs (Nixon 1995, Fletcher 1996), and pose serious threats to coastal ecosystems and economies. The large floating mats of algae that form during bloom events can decrease coastal biodiversity by outcompeting perennial algal species and seagrasses for light, space, or nutrients (Valiela et al. 1997, Hauxwell et al. 1998, 2001, Worm \& Lotze 2006). Decomposition of bloom macroalgae also contributes to the occurrence of hypoxic events (Valiela et al. 1997, Raffaelli et al. 1998), 
which can result in mass fish kills (Deacutis \& Oviatt 2004). Moreover, several bloom-forming macroalgal species produce toxic chemicals (Nelson et al. 2003), which may have negative ecological and/or economic consequences.

Determining the effects of herbivores on macroalgal blooms is an important step towards understanding bloom severity and persistence. Several studies have observed herbivores exerting significant top-down control on macroalgal bloom species (Geertz-Hansen et al. 1993, Korpinen et al. 2007), though this effect has been shown to decrease with increasing nutrients (Horne et al. 1994, Worm \& Lotze 2006). In addition, grazer preferences can differentially influence which algal species are present in blooms, with less palatable species becoming dominant (Lotze \& Worm 2000, Lotze et al. 2001, Nelson et al. 2008). Further complicating our understanding of herbivore-bloom relationships, herbivores can have a positive effect on bloom species by increasing the amount of nitrogen available (Fong et al. 1997) or consuming epiphytes (Kamermans et al. 2002).

In this study, we explored the relationship between herbivores and bloom-forming algae by examining the effect of the mud snail Ilyanassa obsoleta on the growth of Ulva lactuca. I. obsoleta is a common inhabitant of sheltered intertidal and subtidal soft sediment communities in eastern North America (Crisp 1969, Curtis \& Hurd 1981), where it can occur in densities of over $1400 \mathrm{~m}^{-2}$ (C. S. Thornber unpubl. data). I. obsoleta often co-occurs with $U$. lactuca, which can exceed densities of $1600 \mathrm{~g}$ wet mass $\mathrm{m}^{-2}$ during bloom events. While $I$. obsoleta is primarily a deposit feeder, it is also an opportunistic consumer of carrion and possesses a crystalline style for the digestion of plant materials (Curtis 1980). Macroalgae form a regular component of the mud snails' diet (Scheltema 1964, Curtis \& Hurd 1981, Edwards \& Welsh 1982) and mud snails have been found to decrease $U$. lactuca biomass in the laboratory (Giannotti \& McGlathery 2001). However, our preliminary laboratory experiments conducted in 2006 showed no negative effect of mud snail grazing on $U$. lactuca growth (C. S. Thornber unpubl. data). Therefore, our study first addressed whether I. obsoleta grazing decreases $U$. lactuca biomass or facilitates increased growth. Through a series of feeding assays that paired various densities of mud snails with $U$. lactuca, we demonstrated that I. obsoleta positively influences $U$. lactuca growth rates. Next, we investigated the mechanism underlying this facilitation, by examining $U$. lactuca performance when exposed to I. obsoleta nitrogenous excretions, physical contact (implying a reaction to $I$. obsoleta chemical cues as observed in a terrestrial plant-herbivore interaction; Dyer et al. 1995), and grazing of microalgal films. We discuss our results in the context of herbivore effects on macroalgal blooms and the potential implications this has for bloom severity and persistence.

\section{MATERIALS AND METHODS}

Study species and locale. Narragansett Bay, Rhode Island, USA, is a well-mixed estuarine system of $\sim 370 \mathrm{~km}^{2}$. During the summer in the shallow, protected areas of Narragansett Bay, macroalgal blooms composed of Ulva lactuca and tubular Ulva species (Chlorophyta) are a regular occurrence (Granger et al. 2000, C. S. Thornber unpubl. data). U. lactuca blades are distromatic, typically growing attached to hard substrates, but blades can detach and continue growing in the water column. Currently, U. lactuca is the only recorded species of blade-forming Ulva in Rhode Island waters. However, Ulva species are notoriously difficult to identify based on morphology alone and the genus is under taxonomic revision in this area.

Ilyanassa obsoleta is the most abundant invertebrate epibenthic species found in intertidal and shallow subtidal estuarine habitats of Narragansett Bay ( $M$. Guidone \& C. S. Thornber unpubl. data). During bloom events, floating and washed up U. lactuca are found covered with these mud snails, which appear to be grazing across the blades ( $\mathrm{M}$. Guidone pers. obs.).

We conducted all feeding experiments at the University of Rhode Island's Bay Campus (Narragansett, RI, USA) in outdoor flow-through seawater tables during the summers of 2006, 2007, and 2008. The tables were supplied with filtered, ambient temperature seawater from Narragansett Bay. Replicates were held within the seawater tables in $2.5 \mathrm{l}$ semitransparent plastic buckets (we used 51 buckets for nitrogen input experiments only); several meshcovered holes in the sides of each bucket allowed for sufficient seawater flow. Buckets were covered with clear Plexiglas to prevent the input of outside nutrient sources and rainwater.

Feeding assays. Unless otherwise noted, we used juvenile Ilyanassa obsoleta (10 to $14 \mathrm{~mm}$ in length) in all experiments, since they have a lower incidence of parasitic infection that can affect feeding rates (Curtis \& Hurd 1983). In addition, all pieces of Ulva lactuca were between 0.65 and $1.25 \mathrm{~g}$ wet mass.

Our initial feeding assay was conducted using 4 Ilyanassa obsoleta in each of 20 experimental buckets. An equal number of non-herbivore controls were run concurrently; to maintain consistency, control algae were taken from the same thalli as their experimental counterparts in a paired design. We measured wet algal biomass at the beginning and the conclusion of the experiment. We spun each algal piece in a salad 
spinner 20 times to remove excess water prior to measuring its wet mass. Experiments ran for $2 \mathrm{wk}$, as algal tissue begins to degrade after $\sim 2.5 \mathrm{wk}$. Replicates (with matched controls) were removed from the experiment prior to its conclusion in the rare case that more than one-third of the initial algal wet mass was lost. In the few instances where replicates were removed before Day 5 of the experiment, they were excluded from the final data analysis, as these blades were assumed to be in a state of decline prior to the start of the experiment. We repeated this experiment in 2007 with identical methods. To determine if higher densities or different size classes of $I$. obsoleta have a different effect on $U$. lactuca biomass, we conducted 4 additional experiments using the following numbers and sizes of I. obsoleta: 6 juveniles 10-14 mm in length, 12 juveniles $10-$ $14 \mathrm{~mm}, 5$ adults $>14 \mathrm{~mm}$, and 12 recruits $<10 \mathrm{~mm}$. Each combination had 10 replicates with an equal number of non-herbivore controls; all other methods were the same as those used in the initial non-choice assay. Following the conclusion of these experiments, 29 of the snails (25 juveniles and 4 adults) were haphazardly chosen for gut content analysis. These snails were placed in ethanol and transferred to the laboratory, where we extracted their gut contents and determined their composition using light microscopy.

In addition, due to our field observations that Ilyanassa obsoleta is present on washed up algae during low tide, we also assessed whether I. obsoleta would consume Ulva lactuca under low tide conditions. Low tide was simulated every other day for $4 \mathrm{~h}$ by lowering the water level in the tanks from 10 to $1 \mathrm{~cm}$. We used 3 I. obsoleta in each of 10 replicates, with an equal number of controls; initial and final wet mass for each replicate was measured as previously described. Additionally, we measured the initial and final organic content, calculated as percent ash-free dry mass, of the U. lactuca by combusting a portion of each replicate thallus (with a known dry mass) in a muffle furnace for $2 \mathrm{~h}$ at $500^{\circ} \mathrm{C}$ and weighing the resulting mass (Thornber et al. 2006).

As all experiments resulted in increased growth of Ulva lactuca in the presence of Ilyanassa obsoleta (see 'Results'), we conducted 3 additional manipulative experiments to determine the likely cause(s) of this growth. (1) We tested whether nutrient input via $I$. obsoleta defecation could be the cause of the increased growth in the presence of I. obsoleta. We used the same methods described for our initial feeding assays, except that we used 51 buckets and prevented snail grazing by sequestering the 3 I. obsoleta within a small plastic cage with mesh holes in the side, allowing water and nutrient exchange to occur while preventing direct contact between the snails and algae. Caged snails were not provided with an additional food source. However, feces were present throughout the experiment, indicating that microalgal fouling inside the cages was a sufficient food source. We measured the initial and final wet mass and organic content of each algal piece as described above, as well as the initial and final percentage of nitrogen of algal tissues using a continuous flow, isotope mass spectrometer located at the US EPA Atlantic Ecology Division in Narragansett, Rhode Island.

(2) We tested whether Ilyanassa obsoleta contact with the Ulva lactuca was responsible for facilitating $U$. lactuca growth, which would indicate a potential influence from I. obsoleta saliva or other chemical cues. In this experiment, $U$. lactuca in the herbivore treatment were exposed to snails without grazing by dragging a deshelled $I$. obsoleta body across the length of each blade 20 consecutive times every other day. To ensure that this contact was not damaging the blades or having an effect by removing epiphytic microalgae, we included a contact control treatment where a finger was dragged across each blade 20 consecutive times, replicating the contact from the herbivore treatment. An equal number of unmanipulated controls were run concurrently. Each of the 3 treatments had 15 replicates; initial and final wet mass and organic content were measured as described above.

(3) We conducted 2 experiments to determine if Ilyanassa obsoleta were primarily grazing the microalgal films on the Ulva lactuca blades, rather than grazing the blades themselves. For the first experiment, forty $100 \mathrm{~cm}^{2}$ pieces of fiberglass window screening $\left(1 \mathrm{~mm}^{2}\right.$ mesh) were weighed and placed in seawater tables for $2 \mathrm{wk}$, to ensure sufficient fouling with microalgae (primarily benthic diatoms). Window screens were then removed from the seawater tables, blotted dry, and weighed to determine the microalgal mass. We then placed 1 screen and 3 I. obsoleta into each of 20 replicate buckets, with an equal number of non-herbivore controls. After 2 wk, all screens were removed and again blotted dry and weighed. For the second experiment, to determine if I. obsoleta graze microalgae off of U. lactuca, we first placed U. lactuca in a flow-through seawater tank prior to the start of the experiment to ensure sufficient fouling (transporting blades from the field to the laboratory typically results in the accidental removal of benthic diatoms). We placed a fouled $U$. lactuca thallus with $3 \mathrm{I}$. obsoleta in each of 10 replicate buckets, with an equal number of non-herbivore controls. We calculated the average microalgal wet mass at the start of the experiment by taking 5 additional $10 \mathrm{~cm}^{2}$ pieces of U. lactuca and rinsing them in distilled water to remove the microalgae; microalgal mass was measured by filtering this water through a Whatman 2 filter $(8 \mu \mathrm{m}$ particle retention) with a known mass. After $2 \mathrm{wk}$, all U. lactuca 
pieces were removed and the final microalgal wet mass was calculated by rinsing a $10 \mathrm{~cm}^{2}$ piece of each $U$. lactuca thallus and filtering through a Whatman 2 filter.

We analyzed the results of all paired designed feeding assays using paired $t$-tests or the Wilcoxon pairedsample tests, where appropriate. The experiment for snail contact was analyzed using one-way ANOVA. Organic content and \% nitrogen were analyzed using repeated measures ANOVAs. When we performed multiple tests, we adjusted p-values using the multistage procedure (Rice 1990). All statistical analyses were conducted with JMP v.7.0.2 (SAS Institute).

\section{RESULTS}

In our Expts 1 and 2 using 4 juvenile Ilyanassa obsoleta, algae in the herbivore treatments grew twice as much as algae in the control treatments (Fig. 1; Expt 1, $t_{15}=5.564, \mathrm{p}<0.0001 ;$ Expt 2 not shown). We obtained similar results when we manipulated snail density and size (Fig. $1 ; 6$ juveniles $10-14 \mathrm{~mm}$ in length, $t_{9}=4.157$, $\mathrm{p}=0.0025 ; 12$ juveniles $10-14 \mathrm{~mm}, t_{9}=6.115, \mathrm{p}=$ 0.0002 ; 5 adults $>14 \mathrm{~mm}, t_{9}=3.395, \mathrm{p}=0.0079$; 12 recruits $<10 \mathrm{~mm}, t_{9}=2.641, \mathrm{p}=0.0269$ ). Of the 29 mud snails that had their gut contents examined, only 4 contained $U$. lactuca tissue, while 20 of the mud snail guts contained diatoms.

When we simulated low tide, Ulva lactuca again grew significantly more in the herbivore treatment than in the control (Fig. $1 ; t_{19}=3.381, p=0.003$ ). The mean initial organic content of the U. lactuca tissue

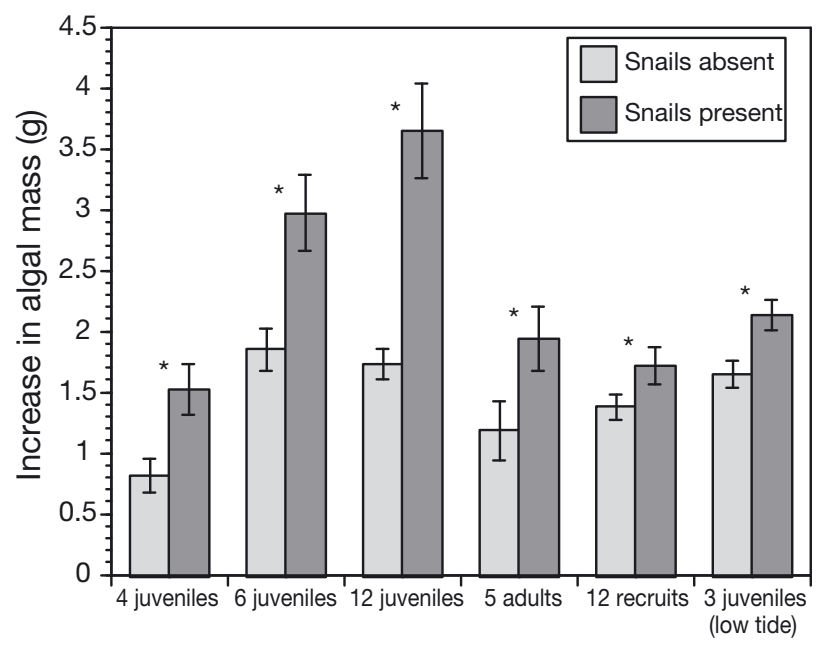

Fig. 1. Ulva lactuca. Changes of algal wet mass (means $\pm 1 \mathrm{SE}$ ) in 6 feeding assays and various densities and size classes of Ilyanassa obsoleta (juveniles $=10-14 \mathrm{~mm}$ in length, adults $>14 \mathrm{~mm}$, recruits $<10 \mathrm{~mm}$ ). All experiments ran for $2 \mathrm{wk}$. ${ }^{*}$ Significant $(p<0.05)$ difference between treatments
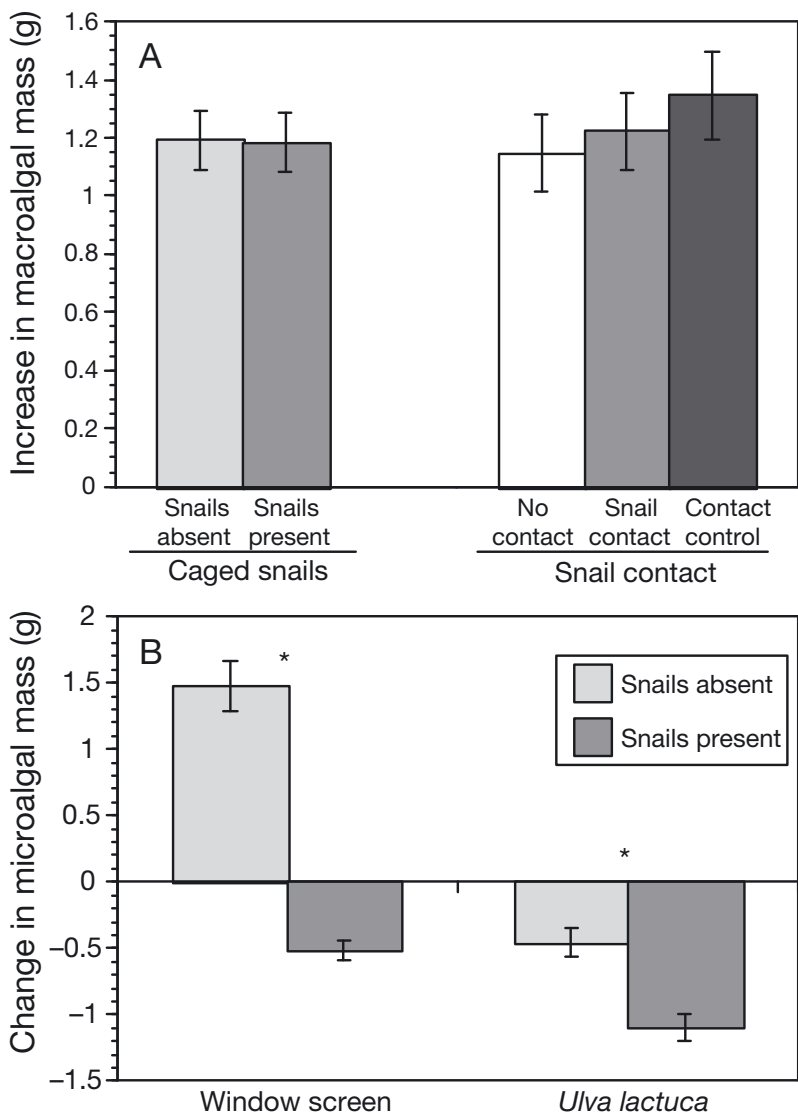

Fig. 2. Ulva lactuca. Experiments examining the potential cause(s) of facilitated growth. (A) Changes in macroalgal mass (means $\pm 1 \mathrm{SE}$ ) in the presence or absence of caged Ilyanassa obsoleta and after contact with deshelled I. obsoleta bodies or controls. (B) Changes in microalgal wet mass (means $\pm 1 \mathrm{SE}$ ) in experiments examining I. obsoleta consumption of microalgae grown on window screen and U. lactuca. ${ }^{*}$ Significant $(\mathrm{p}<0.05)$ difference between treatments

was $73.34 \%$; it did not change significantly over the course of the experiment $\left(F_{1,38}=0.00002, \mathrm{p}=0.98\right)$.

Increased growth rates of experimental thalli disappeared when we caged the snails within our buckets; we found no significant difference in Ulva lactuca growth between treatments with and without caged snails (Fig. $2 \mathrm{~A}_{i} W=6.50, \mathrm{p}=0.79$ ). While organic content of $U$. lactuca increased significantly from the start to the end of the experiment $\left(F_{1,32}=4.89, \mathrm{p}<\right.$ 0.0001; Table 1), there was no significant difference in the increase in organic content between treatments $\left(F_{1,32}=1.13, \mathrm{p}=0.29\right)$. Nitrogen content decreased significantly from the start to the end of the experiment $\left(F_{1,32}=1.44, \mathrm{p}<0.0001\right.$; Table 1$)$; there was no significant difference in the decrease in $\%$ nitrogen between treatments $\left(F_{1,32}=0.45, \mathrm{p}=0.5\right)$, indicating the algae did not respond to nutrients released by snail feces. 
Table 1. Ulva lactuca. Percent organic content and percent nitrogen for the experiment examining nitrogen inputs by caged Ilyanassa obsoleta. Values are means $\pm 1 \mathrm{SE}$

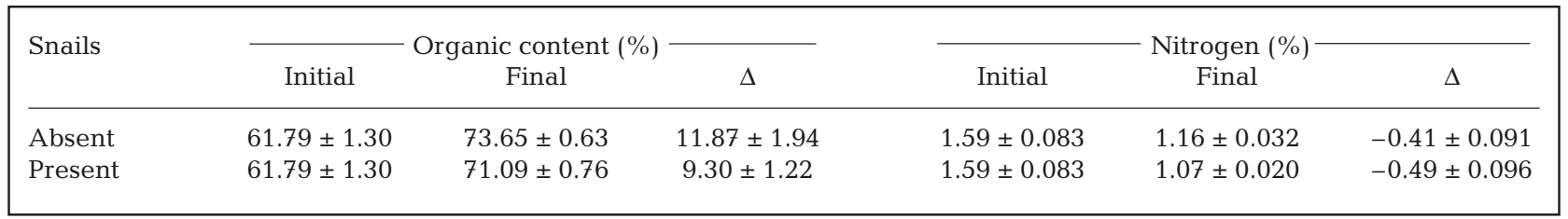

We also found no significant difference in Ulva lactuca growth among treatments in the mud snail contact experiment (Fig. 2A; $F_{2,42}=0.68, \mathrm{p}=0.51$ ), indicating that snail contact alone does not trigger increased algal tissue growth. Organic content in this experiment decreased significantly from the start to the end of the experiment by $\sim 8 \%\left(F_{1,42}=2.06, \mathrm{p}<0.0001\right)$; this decrease did not differ significantly among the treatments $\left(F_{2,42}=2.54, \mathrm{p}=0.09\right)$.

By contrast, we found a 2-fold decrease in microalgal biomass in the presence of herbivores compared to non-herbivore controls. This was true for substrates of window screening (Fig. $2 \mathrm{~B}_{;} t_{19}=8.73, \mathrm{p}<0.0001$ ) as well as Ulva lactuca blades (Fig. $2 \mathrm{~B}_{;} t_{9}=-5.54, \mathrm{p}=$ $0.0004)$. The reduction of microalgal wet mass on $U$. lactuca in both treatments is likely the result of spinning the algae to remove excess water prior to obtaining the final $U$. lactuca wet mass, as diatom removal occurred following this step. However, microalgal wet mass had a significantly greater decrease in the treatment with herbivores.

\section{DISCUSSION}

Increased plant growth resulting from light to moderate herbivory is a common phenomenon in terrestrial plants and occurs due to a wide variety of mechanisms including overcompensation in response to grazer damage, nutrient additions via grazer defecation, and the removal of neighboring competitors (McNaughton 1983, Agrawal 2000). Herbivores can also positively affect macroalgal growth through the addition of nutrients (Fong et al. 1997) and, in a situation similar to the removal of neighboring competitors, grazers can preferentially remove epiphytes that grow on algal blades (Dudley 1992, Littler et al. 1995, Kamermans et al. 2002, Jormalainen et al. 2003, Råberg \& Kautsky 2008). In our study, Ulva lactuca growth was greatest when snails grazed directly on the blades; this was true for experiments that simulated subtidal and low tide conditions. We found no evidence for increased U. lactuca growth from snail contact alone. The facilitation we observed was neither due to the mud snails' nitrogenous wastes, since growth rate differences disap- peared when mud snails were present but restricted from grazing on the blades. In addition, analyses showed no differences in tissue content between algae in the herbivore and control treatments, indicating that the algae were not storing the nitrogen for future growth. An alternative explanation for these results is that the rate of snail defecation was insufficient to raise nitrogen levels in the caged treatments. However, even though snail diets were not supplemented with additional food, we believe this is an unlikely possibility given that snail feces were present each time the buckets were removed from the seawater tanks to measure algal wet mass, which occurred every 3 to $4 \mathrm{~d}$.

The observed algal growth is most likely caused by the removal of the microalgal films that are typically found growing on the Ulva lactuca blades. Our results clearly show that Ilyanassa obsoleta prefer to graze these microalgae rather than consume the U. lactuca blades directly; in both experiments where microalgal biomass was measured, it was significantly lower when the snails were present. Given that mud snails are primarily deposit feeders and have been observed to graze across $U$. lactuca blades in the field, their consumption of the fouling microalgae is not entirely surprising. What is unexpected is that, despite being capable of consuming U. lactuca tissue (Scheltema 1964, Curtis \& Hurd 1981, Giannotti \& McGlathery 2001, present study), I. obsoleta preferentially consume the microalgae on the $U$. lactuca blades to the extent that they have a positive effect on U. lactuca growth. Similarly, Kamermans et al. (2002) observed an increase in $U$. lactuca growth in the presence of amphipods that consumed diatom films. Increased growth of $U$. expansa was also observed in the presence of horn snail grazing by Fong et al. (1997), who attributed this to horn snail movement within the sediment layer releasing nitrogen to the water column. However, the researchers also observed that the snails were not consuming the $U$. expansa, but were grazing over the surface of the blade and the tank, assumingly consuming the microalgal and bacterial films growing on these surfaces. Positive grazer effects due to epiphyte removal have also been found for the freshwater green alga Cladophora glomerata (Dudley 1992), the brown alga Fucus vesiculosus (Jormalainen et al. 2003, 
Råberg \& Kautsky 2008), the red coralline algae Porolithon pachydermum (Littler et al. 1995) and Neogoniolithon strictum (Stachowicz \& Hay 1996), and a variety of seagrass species (Hughes et al. 2004, Heck \& Valentine 2006).

In our experiments, while gut contents indicated that Ilyanassa obsoleta occasionally consume Ulva lactuca, the presence of $I$. obsoleta still significantly increased $U$. lactuca growth. In contrast, Giannotti \& McGlathery (2001) observed that I. obsoleta consumed significant amounts of $U$. lactuca biomass. Differences in experimental design may explain this discrepancy, as Giannotti \& McGlathery (2001) placed sediment in the bottom of their replicates. We did not use sediment in our replicate buckets so that we could mimic the interaction of $I$. obsoleta grazing on floating and washed up algal mats, where the snails do not have direct access to the sediment surface (however, grazing experiments using these species with sediment present have yielded similar findings to ours; A. Tyler pers. comm.). The difference in our findings may also reflect population or species-level differences between Rhode Island and Virginia mud snails and/or Ulva. Regardless of the source of this discrepancy, since our results are consistent across 3 summers, different mud snail densities, and treatments simulating subtidal and intertidal conditions, we conclude our results demonstrate a real, positive effect of I. obsoleta grazing on U. lactuca blade growth.

Bottom-up forces have long been linked to macroalgal blooms (Nixon 1995, Fletcher 1996, Valiela et al. 1997). Our results suggest that the top-down effects of herbivores may also contribute to the excessive growth observed during macroalgal bloom events. While topdown effects are not traditionally thought of as having large positive effects in eutrophic areas, similar positive top-down effects have been observed in seagrass systems. Several seagrass studies that have simultaneously manipulated nutrient levels and mesograzer abundance have found that mesograzers can control epiphyte fouling, even at high nutrient levels (Neckles et al. 1993, Williams \& Ruckelshaus 1993, Heck et al. 2000). Seagrass habitats also serve as a model system, highlighting the complexities of plant-epiphytegrazer relationships that likely occur in other ecosystems, including algal bloom communities. Studies that have examined the effects of more than one mesograzer species on seagrass fouling have found that the impact of each individual species is not always the same as the impact of the species combined (Jernakoff \& Nielson 1997, Duffy et al. 2001, Duffy \& Harvilicz 2001). The outcomes of these interactions become even more complex as higher trophic levels are added (Heck et al. 2006). We conclude that the positive impact of Ilyanassa obsoleta grazing on Ulva lactuca growth, coupled with the high densities of mud snails at sites where blooms occur, may act to exacerbate bloom severity and persistence. However, field studies are needed to determine the exact effects of $I$. obsoleta grazing within bloom communities.

Acknowledgements. Funding for this study was provided by Bay Window (NOAA), RI DEM, RI Sea Grant, and the University of Rhode Island. We thank J. Burkhardt and A. Viveiros for their help in the laboratory, R. McKinney with US EPA Atlantic Ecology Division for use of a mass spectrometer, and E. Preisser, N. Rohr, P. Steinberg and 3 anonymous reviewers for reviewing previous versions of this manuscript.

\section{LITERATURE CITED}

Agrawal AA (2000) Overcompensation of plants in response to herbivory and the by-product benefits of mutualism. Trends Plant Sci 5:309-313

Bazely DR, Jefferies RL (1985) Goose faeces: a source of nitrogen for plant growth in a grazed salt marsh. J Appl Ecol 22:693-703

> Crisp M (1969) Studies on the behavior of Nassarius obsoleta (Say) (Mollusca, Gastropoda). Biol Bull (Woods Hole) 136:355-373

Curtis LA (1980) Daily cycling of the crystalline style in the omnivorous, deposit-feeding estuarine snail Ilyanassa obsoleta. Mar Biol 59:137-140

Curtis LA, Hurd LE (1981) Nutrient procurement strategy of a deposit-feeding estuarine neogastropod, Ilyanassa obsoleta. Estuar Coast Shelf Sci 13:277-285

> Curtis LA, Hurd LE (1983) Age, sex, and parasites: spatial heterogeneity in a sandflat population of Ilyanassa obsoleta. Ecology 64:819-828

Deacutis C, Oviatt CA (2004) Eutrophication in Narragansett Bay. $41^{\circ} \mathrm{N} 3: 10-11$

> Dudley TL (1992) Beneficial effects of herbivores on stream macroalgae via epiphyte removal. Oikos 65:121-127

Duffy JE, Harvilicz AM (2001) Species-specific impacts of grazing amphipods in an eelgrass-bed community. Mar Ecol Prog Ser 223:201-211

Duffy J, MacDonald KS, Rhode JM, Parker JD (2001) Grazer diversity, functional redundancy, and productivity in seagrass beds: an experimental test. Ecology 82:2417-2434

Dyer MI, Moon AM, Brown MR, Crossley DA (1995) Grasshopper crop and midgut extract effects on plants: an example of reward feedback. Proc Natl Acad Sci USA 92:5475-5478

Edwards SF, Welsh BL (1982) Trophic dynamics of a mudsnail [Ilyanassa obsoleta (Say)] population on an intertidal mud flat. Estuar Coast Shelf Sci 14:663-686

Fletcher RL (1996) The occurrence of green tides - a review. In: Schramm W, Niehuis PK (eds) Marine benthic vegetation: recent changes and the effects of eutrophication. Springer, Berlin, p 7-43

Fong P, Desmond JS, Zedler JB (1997) The effect of a horn snail on Ulva expansa (Chlorophyta): consumer or facilitator of growth? J Phycol 33:353-359

> Geertz-Hansen O, Sand-Jensen K, Hansen DF, Christiansen A (1993) Growth and grazing control of abundance of the marine macroalga, Ulva lactuca L. in a eutrophic Danish estuary. Aquat Bot 46:101-109

Giannotti A, McGlathery K (2001) Consumption of Ulva lactuca (Chlorophyta) by the omnivorous mud snail Ilyanassa osoleta (Say). J Phycol 37:209-215 
Granger SL, Mark J, Buckley BA, Schwartz M (2000) An assessment of eutrophication in Greenwich Bay, Vol 1. Rhode Island Sea Grant, Narragansett, RI

Gronemeyer PA, Dilger BJ, Bouzat JL, Paige KN (1997) The effects of herbivory on paternal fitness in scarlet gilia: better moms also make better pops. Am Nat 150:592-602

> Hauxwell J, McClelland J, Behr PJ, Valiela I (1998) Relative importance of grazing and nutrient controls of macroalgal biomass in 3 temperate shallow estuaries. Estuaries 21: $347-360$

Hauxwell J, Cebrian J, Furlong C, Valiela I (2001) Macroalgal canopies contribute to eelgrass (Zostera marina) decline in temperate estuarine ecosystems. Ecology 82:1007-1022

> Heck KL Jr, Valentine JF (2006) Plant-herbivore interactions in seagrass meadows. J Exp Mar Biol Ecol 330:420-436

$>$ Heck KL, Pennock JR, Valentine JF, Coen LD, Sklenar SA (2000) Effects of nutrient enrichment and small predator density on seagrass ecosystems: an experimental assessment. Limnol Oceanogr 45:1041-1057

> Heck KL Jr, Valentine JF, Pennock JR, Chaplin G, Spitzer PM (2006) Effects of nutrient enrichment and grazing on shoalgrass Halodule wrightii and its epiphytes: results of a field experiment. Mar Ecol Prog Ser 326:145-156

Horne A, McClelland J, Valiela I (1994) The growth and consumption of macroalgae in estuaries: the role of invertebrate grazers along a nutrient gradient in Waquoit Bay, Massachusetts. Biol Bull (Woods Hole) 187:279-280

- Hughes AR, Bando KJ, Rodriguez LF, Williams SL (2004) Relative effects of grazers and nutrients on seagrasses: a meta-analysis approach. Mar Ecol Prog Ser 282:87-99

> Jernakoff P, Nielson J (1997) The relative importance of amphipod and gastropod grazers in Posidonia sinuosa meadows. Aquat Bot 56:183-202

Jormalainen V, Honkanen T, Koivikko R, Eränen J (2003) Induction of phlorotannin production in a brown alga: defense or resource dynamics? Oikos 103:640-650

Kamermans P, Malta EJ, Verschuure JM, Schrijvers L, Lentz LF, Lien ATA (2002) Effect of grazing by isopods and amphipods on growth of Ulva spp. (Chlorophyta). Aquat Ecol 36:425-433

Korpinen S, Jormalainen V, Honkanen T (2007) Effects of nutrients, herbivory, and depth on the macroalgal community in the rocky sublittoral. Ecology 88:839-852

- Lennartsson T, Tuomi J, Nilsson P (1997) Evidence for an evolutionary history of overcompensation in the grassland biennial Gentianella campestris (Gentianaceae). Am Nat 149:1147-1155

> Littler MM, Littler DS, Taylor PR (1995) Selective herbivory increases biomass of its prey: a chiton-coralline reefbuilding association. Ecology 76:1666-1681

Lotze HK, Worm B (2000) Variable and complementary effects of herbivores on different life stages of bloomforming macroalgae. Mar Ecol Prog Ser 200:167-175

Lotze HK, Worm B, Sommer U (2001) Strong bottom-up and top-down control of early life stages of macroalgae. Limnol Oceanogr 46:749-757

McNaughton SJ (1979) Grazing as an optimization process:

Editorial responsibility: Peter Steinberg,

Sydney, New South Wales, Australia grass-ungulate relationships in the Serengeti. Am Nat 113:691-703

McNaughton SJ (1983) Compensatory plant growth as a response to herbivory. Oikos 40:329-336

> McNaughton SJ (1997) Promotion of the cycling of dietenhancing nutrients by African grazers. Science 278: 1798-1800

Neckles H, Wetzel R, Orth R (1993) Relative effects of nutrient enrichment and grazing on epiphyte-macrophyte (Zostera marina L.) dynamics. Oecologia 93:285-295

Nelson TA, Lee DJ, Smith BC (2003) Are 'green tides' harmful algal blooms? Toxic properties of water-soluble extractions from two bloom-forming macroalgae, Ulva fenestrata and Ulvaria obscura (Ulvophyceae). J Phycol 39: 874-879

> Nelson TA, Haberlin $\mathrm{K}$, Nelson AV, Ribarich H and others (2008) Ecological and physiological controls of species composition in green macroalgal blooms. Ecology 89: $1287-1298$

Nixon S (1995) Coastal marine eutrophication: a definition, social causes, and future concerns. Ophelia 41:199-219

> Nolet BA (2004) Overcompensation and grazing optimisation in a swan-pondweed system? Freshw Biol 49:1391-1399

Paige KN (1999) Regrowth following ungulate herbivory in Ipomopsis aggregata: geographic evidence for overcompensation. Oecologia 118:316-323

> Råberg S, Kautsky L (2008) Grazer identity is crucial for facilitating growth of the perennial brown alga Fucus vesiculosus. Mar Ecol Prog Ser 361:111-118

Raffaelli DG, Raven JA, Poole LA (1998) Ecological impact of green macroalgal blooms. Oceanogr Mar Biol Annu Rev $36: 97-125$

> Rice WR (1990) A consensus combined p-value test and the family-wide significance of component tests. Biometrics 46:303-308

> Scheltema RS (1964) Feeding habits and growth in the mudsnail Nassarius obsoletus. Chesapeake Sci 5:161-166

Stachowicz JJ, Hay ME (1996) Facultative mutualism between an herbivorous crab and a coralline alga: advantages of eating noxious seaweeds. Oecologia 105:377-387

Thornber C, Stachowicz JJ, Gaines S (2006) Tissue type matters: selective herbivory on different life history stages of an isomorphic alga. Ecology 87:2255-2263

Valentine JF, Heck KL, Busby J Jr, Webb D (1997) Experimental evidence that herbivory increases shoot density and productivity in a subtropical turtlegrass (Thalassia testudinum) meadow. Oecologia 112:193-200

Valiela I, McClelland J, Hauxwell J, Behr PJ, Hersh D, Foreman K (1997) Macroalgal blooms in shallow estuaries: controls and ecophysiological and ecosystem consequences. Limnol Oceanogr 42:1105-1118

Williams SL, Ruckelshaus MH (1993) Effects of nitrogen availability and herbivory on eelgrass (Zostera marina) and epiphytes. Ecology 74:904-918

> Worm B, Lotze HK (2006) Effects of eutrophication, grazing, and algal blooms on rocky shores. Limnol Oceanogr 51:569-579

Submitted: August 5, 2010; Accepted: October 25, 2010

Proofs received from author(s): December 7, 2010 